\title{
In Which the River Makes Off with Three Stationary Characters
}

In the seventeenth century, his Holiness the Pope adjudged beavers to be fish. In retrospect, that was a zoologically illogical decision; but the beavers were not miffed at being changed into fish. In any case, they decided not to truckle to their new specification, not to be perfect fish, textbook fish; instead they became fanciful fish, the first to have furry babies, the first to breathe air and the first fish to build for themselves commodious conical fortresses in the water. If Prince Maximilian, traveling up the Missouri River, had taken it in mind to recategorize them as Druids or flamingoes, beavers would have become toothy Druids, or portly brown industrious flamingoes.

The beavers' reaction to the papal renaming highlights two of their especial qualities: their affability and their unyieldingness. They affably yield not. They live in cold wet water but are warm and dry in their oily parkas; if they are deemed fishes, they respond by becoming lumberjacking fishes. They-of-the-Incisors are puppets of no pope, and puppets of no river, either. The river, where the beaver lives, is at cross-purposes with the beaver, in that it is tumbling away, while the beaver wants to produce kindred at One Address. An animal more contrary than the beaver would build a grumpy shanty of sticks in the forest; an animal less contrary the river would drag and distract and make into memorabilia.

The Moon also graces the water without getting floated off its feet, but effortlessly, while beavers have to work as hard as trucks. What it takes for them to prepare a mansion for themselves, in the midst of gallivanting water, with nothing to wield but short arms and long teeth, is constant botheration; they chew and lug and wrestle logs all night long, unless wolverines or humans visit. When these disputatious creatures turn up, the beavers swim to the underwater tunnel to their cabin and climb up and hide out, for they do not like to fight.

Beaver babies cannot sink or swim when they are born; if they accidentally slip down the tunnel into the water they are like tiny complaining pontoons. In several hours, though, they can swim, front paws up by their chins, paddling with their huge ducky back188 
feet; and by May, after drinking a month's worth of fat buttery milk, the burnished brown babies are working, swimming their little twigs to the dam to help with repairs.

They will never stop working thereafter, unless one of them happens to be voted an extraneous beaver, during the periodic population control that beaverocracies exercise. Even the most agreeable animals can only stand so many of themselves per pond. An expelled beaver by himself will just crouch in a mudhole, like a mouldywarp, and have time to get lost in thought; unlike his cousins and brothers and grandmothers chewing down four hundred trees every year; careening away when the trees start to fall over; shuffling back to drag the timber through the grass, wrangling poplars and birches and piano benches-whatever is wooden; digging log flumes and making log-rolling paths, swimming the trees down the stream, shoving them together into a dam, making the dam wider each night and higher and higher, repairing the dam when a leak springs; heaping up a house of aspens, trundling down the shore with armfuls of muddy rubble to plaster the walls with, repairing the roof after a bear performs roof meddlement, plunging cherry trees underwater in order to have sumptuous foodstuffs in the larder in January, for the Feast of the Bean-King, when ponds are covered with two feet of ice.

With their powers of reorganization, beavers recapitulate the creation of the world, gathering water together in one place and making dry mounds appear in another. In fact they were probably there at the original one, acting as auxiliary spirits, helping to impose landscape on the mishmash, heaping up dry land for the earthgoers and corralling the waters for swimming animals. How boggy and spongelike would the world be without beavers to divide it up! What type of tenants would we attract but bladderworts and mudpuppies!

But even if they were the ones who installed it, beavers are still subject to topography. A river's patron-glacier may melt so catastrophically that the river overthrows a beaver dam, and before they can mobilize Barrier Repair, the beaver colony gets bundled off to sea, like fat astonished fishes. Though octopuses make sense in the ocean, beavers and cactuses and pencilmakers do not. When they get there the ocean must derange them, making them delirious, because the sound of water is what triggers their gnawing reflex. 
As soon as they hear the burbly gushing of a stream, beavers speed to the nearest trees to chisel girdles around their trunks so they go whomping down and then they can stuff them into the chatterboxy river to strangulate it into silence. But the ocean is a wilderness of chatter, and not in all the forests of the world are there enough trees to muzzle its splashing, sloshing, gurgling, yammering, yackety-yacking waves.

Late in life, when chinook salmon are old salts, long having lived at sea, they decide to hoist themselves up a river, back up to the scene of their nativity, with its particular mushroom-and-lily perfume. They smell their way there. If you subtracted the mushrooms and the lilies and substituted some frumenty and glögg and sagittaries with beer-breath, how would the fishes recognize their birthplace? They would slog right past it, up a tributary creek until they got to the icy seep of the river's tiny origination faucet.

The brides and grooms toil up their 900-mile aisle for weeks and weeks to reach the mushroomy wedding spot. This is notable, although the Muses probably travel farther, from wherever they live-which we assume because the Muses seem frazzled, once they get to Earth, in how they offload their fancies, strewing them down in a boggledy-botch. But chinooks neatly, perfectionistically, deposit their ingredients in the bottom-gravel-ingredients which when congealed will result in seven thousand black-eyed eggs.

Once the spiffy little fishes have hatched from their eggs and self-excavated from the gravel, they hide in crannies and absorb the yolks bequeathed to them. Then the bequests run out; then they swim in place and hold their mouths open to swallow the crustaceans drifting by. Not inheriting little grapnel anchors to hook into the riverbed, the fishes countervail the flow of the river by plying their fins, making endless varieties of strokes, all of which mean No. Maybe it feels like being tossed endless apples while trying to retain a total of zero apples. Maybe it feels like maintaining the same longitude on a steam train going east.

The little open-mouthed fishes swim against the river for one and a half years, returning to where they are every moment, exercising all their hydrodynamical competence in not being spun around to the left or to the right, in not pitching head-over-tail or tail-overhead, in not getting rolled sideways like cartwheels in the cur- 
rent-the influential current of ambient custom which would draw all creatures pitching, yawing, rolling down its sinuous swallowing throat, all creatures become gobbets.

The salmon fry live in this milieu as dissenters, like the beavers; and they also labor relentlessly to stay in one place-not by concocting deluxe accommodations for themselves, but by sculling their delicate translucent fins all winter, spring, summer, fall. Their willfulness is their anchor. You would think, after eighteen months, that the anchor was permanent, that No was the only word they knew, that they would forever correct for the vector of the river.

Then something countervails their will to countervail. Their will tips over and they let the water swoop them away, spilling them backwards down churning frothy staircases of rocks, rushing them through ice-blue hourglasses between basaltic cliffs covered with maiden-hair ferns, flicking them down to the fluted mud, where rest jettisoned peacepipes and scarfpins, streaming them under mossy sodden maples and sodden mossy yews, crisscross-fallen in the water, pouring them over shallow stony flats, dilly-dallying them around lazy crooks and switches, past yellow monkeyflowers on the shore and elfin groves of watercress, depositing them at last in the very vasty habitat of octopuses.

Usually when you go to a dance, the dancing master marches onto the stage, starts cranking the handle of his hurdy-gurdy organ, then bellows instructions to the crowd: "Take your partner by the hand!" "Now turn to the right, now turn about; to the left, or you are out!" "Now trip between Johnny and Jean!" "Now cut your capers; put your legs to't; and show that you can do't!" "Frisk, frisk it away!" "Now the dance is at an end!" He instructs you through his ruly compendium of jigs; and some you dance right and some you dance wrong, but the capers feel cranked-out, and in the morning trudging home, what have you frisked away but the night? It feels like smiling when you're sad, or treading the wellhouse wheel.

But sometimes on a porch in June, a girl begins to plunk her banjo, warmly; and after a spell of stillness, while the sound travels down their ear crinkles into their inmost feeling-chambers, the music starts to dance the people passing by. They toss like puppets on a bouncing sheet; like boys without a boat; they swing like 
weeds in the wind; they leap heptangularly about, dancing eccentric saltarellos, discovering that their springs are not so rusty.

For even if you have built masterful aspen castles in your mind, have toppled whole forests to throttle the writhing elements into a liveably serene personal pond; if you have longtime sculled your ingenious fins to withstand the tumble-crazy currents-or on the other hand, if you have been frantically stationary, wishing to spin or be spun but being suspended; there is music that will dissolve your anchors, your sanctuaries, floating you off your feet, fetching you away with itself. And then you are a migrant, and then you are amuck; and then you are the music's toy, juggled into its furious torrents, jostled into its foamy jokes, assuming its sparklyblue or greenweedy or brownmuddy tinges, being driven down to the dirgy bottom where rumble-clacking stones are lit by waterlogged and melancholy sunlight, warping back up to the surface, along with with yew-leaves and parallel mittens and alewives and frogbones and other strange acquisitions snagged and rendered willy-nilly by the current, straggling away on its rambling fiddly cadenzas, with ever-changing sights-freckled children on the bank, chicken choirs, brewing thunderclouds, pixies perched in wild parsley-until it spills you into a place whose dimensions make nonsense of your heretofore extraordinary spatial intelligence. 